\title{
A EXIGIBILIDADE DE SEGURO DE RESPONSABILIDADE CIVIL POR DANO AMBIENTAL COMO CONDICIONANTE DO LICENCIAMENTO AMBIENTAL BRASILEIRO
}

\section{THE REQUIREMENT OF CIVIL LIABILITY INSURANCE FOR ENVIRONMENTAL DAMAGE AS A CONDITIONER FOR BRAZILIAN ENVIRONMENTAL LICENSING}

\section{Luís Fernando Massonetto ${ }^{1}$ Vinícius Monte Custodio ${ }^{2}$}

\section{RESUMO}

Este artigo analisa, do ponto de vista da dogmática jurídica, seguindo o método do pós-positivismo jurídico, se o seguro de responsabilidade civil por dano ambiental pode ser exigido como condicionante do licenciamento ambiental na ausência de expressa previsão legal. Esta pesquisa não se propõe a realizar análise econômica do direito nem a enfrentar as dificuldades metodológicas desse ramo do mercado securitário. A justificativa da investigação são as insuficiências do direito da responsabilidade civil diante de danos ambientais de grande magnitude e do fenômeno da concorrência de causas, que dificulta ou impossibilita a punição dos responsáveis. A conclusão é que o seguro de responsabilidade civil é exigível pelo órgão licenciador, desde que prevista em regulamento independente e que o empreendimento ou a atividade apresente alto risco.

Palavras-chave: Licenciamento ambiental, Seguro de responsabilidade civil por dano ambiental, Função social do contrato, Princípio da reserva de lei, Impacto ambiental e risco.

\footnotetext{
${ }^{1}$ Professor Doutor de Direito Econômico e Economia Política da Faculdade de Direito da Universidade de São Paulo. Professor do Programa de Pós-Graduação em Cidades Inteligentes e Sustentáveis da UNINOVE. Advogado. Universidade de São Paulo/Professor Doutor de Direito Econômico e Economia Política da Faculdade de Direito, UNINOVE/Professor do Programa de Pós-Graduação em Cidades Inteligentes e Sustentáveis - Brasil. ORCID Id: http://orcid.org/0000-0002-0250-5614 Lattes: http://lattes.cnpq.br/0969838199511588 E-mail: massonetto@usp.br

2 Doutorando em Direito Econômico e Economia Política na Universidade de São Paulo. Mestre em Direito Urbanístico e Direito Ambiental pela Universidade de Coimbra. Advogado. Brasil. ORCID Id: https://orcid.org/0000-0001-6665-817X Lattes: http://lattes.cnpq.br/5227028274432693 E-mail: montecustodio@gmail.com
} 


\section{ABSTRACT}

This article analyses, from the legal dogmatic standpoint, following the legal post-positivism method, whether the environmental liability insurance may be imposed as a condition of the environmental licensing in the absence of express statutory provision. This research does not intend to do an economic analysis of the Law nor to address the methodological difficulties of this branch of the insurance market. The research's justification are the shortcomings of the phenomenon of cause competition, which hinders or prevents the punishment of the liable persons. The conclusion is that the environmental liability insurance is demandable by the licensing body, as long as it is prescribed by an independent administrative regulation and the enterprise or activity poses a high risk.

Keywords: Environmental licensing, Environmental liability insurance, Social function of contract, Principle of legal reserve, Environmental impact and risk.

\section{INTRODUÇÃO}

O presente artigo é um trabalho de dogmática jurídica, assim entendida como o estudo da realidade normativa válida, tomando o direito positivo como o ponto de partida inquestionável, ou axioma, para a aplicação de seu método.

O método escolhido é o pós-positivismo jurídico, pelo que se encarará o direito como um fato orientado a valores, vinculando sua estrutura ao cumprimento duma função. Os valores consagrados pelos princípios jurídicos fundamentais da Constituição da República (CR) são simultaneamente a estrutura e a função do sistema, que orientarão a interpretação e a integração do direito válido.

Trata-se duma análise de direito ambiental brasileiro, cujo problema é saber se, na ausência de expressa previsão legal, é juridicamente exigível dos empreendedores a contratação de seguro de responsabilidade civil por dano ambiental como condicionante do licenciamento ambiental. Portanto, esta pesquisa não pretende fazer análise econômica do direito, tal como a avaliação do custo de oportunidade e das consequências econômicas da exigência de contratação de seguro, nem tampouco se debruçar sobre as dificuldades metodológicas desse ramo do mercado securitário.

A justificativa desta investigação são as dificuldades enfrentadas pelo direito da responsabilidade civil perante danos ambientais de grande magnitude, contra os quais nem sempre o 
patrimônio do criador do risco é suficiente para promover a reparação integral do prejuízo causado, e perante o fenômeno da concorrência de causas, que dilui o nexo de causalidade entre diversos agentes econômicos, dificultando ou impossibilitando a punição dos responsáveis.

A hipótese levantada é que o órgão licenciador competente pode exigir a contratação de seguro de responsabilidade civil como condicionante do licenciamento ambiental, independentemente de intermediação legislativa, desde que: (I) prevista em regulamento independente; e (II) o empreendimento ou a atividade apresente alto risco, pelo cruzamento da matriz de probabilidade ou frequência de ocorrência de danos com a de magnitude de danos, com base em estudo de análise de risco.

Em primeiro lugar, far-se-ão breves apontamentos sobre o contrato de seguro de responsabilidade civil por dano ambiental. Em segundo lugar, mapear-se-á a legislação infranacional sobre seguro de responsabilidade civil por dano ambiental. Em terceiro lugar, mapear-se-ão todos os projetos de lei sobre o tema em tramitação no Congresso Nacional. Em quarto lugar, investigar-se-á até que ponto podem os órgãos licenciadores, à luz do princípio da reserva de lei, exigir a contratação de seguro de responsabilidade civil por danos ambientais, como condicionante do licenciamento ambiental de empreendimentos ou atividades, sem expressa previsão legal. E em quinto lugar, delimitar-se-ão os tipos de empreendimentos ou atividades que podem ser legitimamente sujeitos à contratação de seguro.

\section{I- BREVES APONTAMENTOS SOBRE O CONTRATO DE SEGURO DE RESPONSABILIDADE CIVIL POR DANO AMBIENTAL}

No Código Civil de 1916, o contrato de seguro era o negócio jurídico pelo qual o segurador obrigava-se, mediante o recebimento de um prêmio, a indenizar o segurado por prejuízo resultante de riscos futuros previstos no contrato (art. 1.432). ${ }^{3}$ Com o Código Civil de 2002 (CC), o contrato de seguro passa a ser o negócio jurídico pelo qual o segurador garante interesse legítimo do segurado, relativo a pessoa ou a coisa, mediante o recebimento do prêmio, contra riscos predeterminados (art. 757). ${ }^{4}$

\footnotetext{
3 "Art. 1.432. Considera-se contrato de seguro aquele pelo qual uma das partes se obriga para com outra, mediante a paga de um prêmio, a indenizar-Ihe o prejuízo resultante de riscos futuros, previstos no contrato."

4 "Art. 757. Pelo contrato de seguro, o segurador se obriga, mediante o pagamento do prêmio, a garantir interesse legítimo do segurado, relativo a pessoa ou a coisa, contra riscos predeterminados."
} 
Alheia a essa mudança normativa, a doutrina tradicional, apegada ao individualismo liberal do Código Beviláqua, segue interpretando o contrato de seguro como um negócio jurídico sinalagmático e aleatório, em que o segurado assume obrigação certa de pagar o prêmio fixado na apólice, enquanto a prestação do segurador depende da ocorrência ou não do sinistro. ${ }^{5}$

Sem embargo, assiste razão àqueles que concebem o contrato de seguro, a partir de uma ótica solidarista, como um negócio jurídico transindividual ou comunitário, dado que a determinação do prêmio é proporcional ao risco e este está sujeito às oscilações para cima e para baixo da massa de segurados $^{6}$, e comutativo, dado que a contraprestação do segurador não é a indenização do segurado quando verificado o sinistro, mas a organização empresarial para a garantia desse eventual pagamento. $^{7}$

O próprio conceito de risco foi ampliado e já não se limita a eventos futuros e incertos, agora contemplando "qualquer situação de necessidade financeira que possa ser identificada durante a vigência do contrato do seguro, ainda que decorra de fatos precedentes". 8 O essencial é que o interesse do segurado seja legítimo, assim entendido como "aquele que não contraria a lei, a boa-fé e a moral, normalmente de natureza econômica". ${ }^{9}$ Por isso é nulo o contrato que garante interesse proveniente de ato doloso do segurado, do beneficiário, ou de representante de um ou de outro (art. 762 do CC).

Essa guinada ideológica encontra lastro na própria Constituição, que acolhe os valores sociais do trabalho e da livre iniciativa (art. 1ํ, inciso IV) e a construção de uma sociedade livre, justa e solidária (art. 3ำ, inciso I) como princípios fundamentais da República.

Por esse motivo, a autonomia privada, mais especificamente a autonomia contratual, enquanto desenvolvimento funcional da teoria da autonomia da vontade, hoje só adquire proteção jurídica quando seu suporte fático - a vontade - está direcionado à realização de uma finalidade traçada pelo direito. ${ }^{10}$

\footnotetext{
${ }^{5}$ Cf. GONÇALVES, Carlos Roberto. Direito civil brasileiro, 14. ed. São Paulo: Saraiva, v. 3 (Contratos e atos unilaterais), 2017, p. 561.

${ }^{6}$ Cf. TZIRULNIK, Ernesto. Seguro de riscos de engenharia. Tese (Doutorado em Direito). Faculdade de Direito, Universidade de São Paulo. São Paulo, 2014, p. 36.

${ }^{7}$ Cf. COELHO, Fábio Ulhoa. Curso de direito civil, 5. ed. São Paulo: Saraiva, v. 3 (Contratos), 2012, p. 302.

${ }^{8}$ Cf. TZIRULNIK, Ernesto. op. cit., p. 46.

${ }^{9}$ CAVALIERI FILHO, Sergio. Programa de responsabilidade civil, 9. ed. São Paulo: Atlas, 2010, p. 437.

${ }^{10}$ Cf. FARIAS, Cristiano Chaves de; ROSENVALD, Nelson. Curso de direito civil, 9. ed. Salvador: JusPodivm, v. 4 (Contratos), 2019, p. 156-161.
} 
A liberdade contratual deve ser exercida nos limites da função social do contrato (art. 421 do CC). Em sua perspectiva intrínseca, a função social do contrato visa à justiça, ao equilíbrio e à dignidade da pessoa humana na relação jurídica travada entre as partes do negócio; e em sua perspectiva extrínseca, a função social do contrato visa à proteção de interesses transcendentes aos interesses das partes do negócio, não sendo o contrato apenas um instrumento de circulação de riquezas, mas também de desenvolvimento social. ${ }^{11}$

Quanto à natureza do risco segurado, o seguro pode ser: de dano, quando o interesse legítimo do segurado for relativo a coisa (art. 778 e ss. do CC); ou de pessoa, quando o interesse legítimo do segurado for relativo a pessoa (art. 789 e ss. do CC). Quanto ao regime jurídico aplicável, o seguro pode ser: civil, quando o contratante não é empresário ou a garantia não é insumo de atividade empresarial; ou empresarial, quando o contratante é empresário ou a garantia é insumo de atividade econômica. ${ }^{12}$

O seguro ambiental é um seguro empresarial de dano, expressamente previsto, no art. 9o, inciso XIII, da Lei no 6.938, de 31 de agosto de 1981, como um dos instrumentos da Política Nacional do Meio Ambiente (PNMA). Ele se subdivide em seguro de responsabilidade civil, quando cobre o pagamento de indenização por perdas e danos devidos pelo segurado a terceiros, e em segurogarantia, quando se destina a assegurar ao segurado o cumprimento de uma obrigação pelo tomador do seguro. ${ }^{13}$ Este último subtipo de contrato de seguro não é objeto deste trabalho.

Diferentemente do tratamento conferido a outros instrumentos, como o licenciamento ambiental, que é obrigatório para "a construção, instalação, ampliação e funcionamento de estabelecimentos e atividades utilizadores de recursos ambientais, efetiva ou potencialmente poluidores ou capazes, sob qualquer forma, de causar degradação ambiental" (art. 10 da Lei no 6.938/1981), a PNMA não delimitou quais empreendimentos ou atividades dependem de seguro de responsabilidade civil.

De fato, à exceção da Lei no 12.305, de 02 de agosto de 2010, que institui a Política Nacional de Resíduos Sólidos (PNRS), que faculta ao órgão licenciador do Sisnama "exigir a contratação de seguro de responsabilidade civil por danos causados ao meio ambiente ou à saúde pública" nos casos

\footnotetext{
${ }^{11}$ Cf. GAGLIANO, Pablo Stolze; PAMPLONA FILHO, Rodolfo. Novo curso de direito civil, 2. ed. unificada. São Paulo: Saraiva, v. 4 (Contratos), 2019, p. 98-99.

${ }^{12}$ Cf. COELHO, Fábio Ulhoa. op. cit., p. 302-306.

${ }^{13}$ PEREIRA, Luciana Vianna. Seguro ambiental: o que a legislação pretende e do que o meio ambiente precisa? Revista de Eletrônica da OAB/RJ - Edição Especial - Direito Ambiental, 2017, p. 153-155. Disponível em: http://revistaeletronica.oabrj.org.br/wp-content/uploads/2017/11/PEREIRA-Luciana-Seguro-Ambiental-1.pdf. Acesso em: 07 jul. 2020.
} 
de empreendimentos ou atividades que operem com resíduos perigosos (art. 40), não se tem conhecimento de outra lei federal dispondo sobre a contratação de seguro de responsabilidade civil como condicionante do licenciamento ambiental.

Consequentemente, é polêmica a validade jurídica das condicionantes de licenças ambientais que exigem a contratação de seguro de responsabilidade civil por dano ambiental fora da hipótese do art. 40 da PNRS, já que "ninguém será obrigado a fazer ou deixar de fazer alguma coisa senão em virtude de lei" (art. 5ㅇ, inciso II, da CR).

Mas até que ponto estaria tal exigência alcançada pelo princípio da reserva de lei?

Antes de se enfrentar essa questão, mapear-se-á a legislação infranacional sobre seguro de responsabilidade civil por dano ambiental, bem assim os projetos de lei em tramitação no Congresso Nacional que dispõem sobre esse tema, para uma contextualização mais pormenorizada da discussão.

\section{II - DA LEGISLAÇÃO INFRANACIONAL SOBRE SEGURO DE RESPONSABILIDADE CIVIL POR DANO AMBIENTAL}

Conquanto o art. 22 da CR atribua à União competência privativa para legislar sobre direito civil (inciso I) e sobre seguros (inciso VII), o art. 24 da CR atribui à União, aos Estados e ao Distrito Federal competência concorrente para legislar sobre "florestas, caça, pesca, fauna, conservação da natureza, defesa do solo e dos recursos naturais, proteção do meio ambiente e controle da poluição" (inciso VI), sobre "proteção ao patrimônio histórico, cultural, artístico, turístico e paisagístico" (inciso VII) e sobre "responsabilidade por dano ao meio ambiente, ao consumidor, a bens e direitos de valor artístico, estético, histórico, turístico e paisagístico" (inciso VIII). O art. 30 da CR estende essa competência legislativa concorrente aos municípios, já que lhes cabe "legislar sobre assuntos de interesse local" (inciso I) e "suplementar a legislação federal e a estadual no que couber" (inciso II). ${ }^{14}$

Portanto, ao lado da dimensão legislativa civilista, que enfoca os seguros pela ótica da teoria dos contratos e pela do mercado securitário, existe a dimensão legislativa ambientalista, de âmbitos

14 “O Município é competente para legislar sobre meio ambiente com União e Estado, no limite de seu interesse local e desde que tal regramento seja e harmônico com a disciplina estabelecida pelos demais entes federados (art. 24, VI c/c 30, I e II da CRFB)", SUPREMO Tribunal Federal. RE 586.224/SP (Tribunal Pleno). Diário de Justiça Eletrônico 20 jun. 2008. Rel. Min. Luiz Fux. 
federal, estadual e municipal, que enfoca os seguros como um dos instrumentos econômicos da PNMA. É para esta última dimensão legislativa que este trabalho volta sua preocupação.

Para o levantamento da legislação infranacional sobre seguro de responsabilidade civil por dano ambiental, foram realizadas buscas por palavras-chave no dia 11 de julho de 2020, utilizando-se o termo "seguro ambiental" (sem aspas), nos sítios eletrônicos das Assembleias Legislativas dos 26 estados da federação e no da Câmara Legislativa do Distrito Federal. ${ }^{15}$

No estado do Espírito Santo, a Lei no 9.264, de 15 de julho de 2009, que institui a Política Estadual de Resíduos Sólidos, o único resultado pertinente obtido, limita-se a arrolar "o seguro ambiental, conforme dispuser lei específica", que ainda não existe, como um de seus instrumentos (art. 50, inciso XX).

No estado de Pernambuco, a Lei no 14.249, de 17 de dezembro de 2010, que dispõe sobre o licenciamento ambiental, infrações e sanções administrativas ao meio ambiente, o único resultado obtido, apenas lista o seguro ambiental como um dos instrumentos econômicos da política ambiental (art. 2º, parágrafo único, inciso II), à semelhança da PNMA.

No estado do Rio de Janeiro, a Lei no 4.255, de 29 de dezembro de 2003, que dispõe sobre a instalação e funcionamento de oleodutos, exige "a comprovação de que os interessados providenciaram seguro contra dano ambiental, destinado a cobrir danos ao ecossistema e a terceiros eventualmente prejudicados" como condição prévia para "a instalação ou funcionamento de oleodutos no território fluminense" (art. 2ㅇ). ${ }^{16}$

A busca só encontrou, além desse resultado, a Lei no 7.192, de 06 de janeiro de 2016, oriunda de projeto de iniciativa parlamentar protocolado cinco dias após o desastroso rompimento da barragem da mineradora Samarco no município de Mariana - MG, que estabelece a Política Estadual de Segurança de Barragens e Açudes (PESBA) e regula o Sistema Estadual de Informações sobre Segurança de Barragens e Açudes (SEISBA):

Art. 1 - Esta Lei estabelece a Política Estadual de Segurança de Barragens e açudes (PESBA) e regula o Sistema Estadual de Informações sobre Segurança de Barragens e Açudes (SEISBA), no âmbito do Estado do Rio de Janeiro.

\footnotetext{
${ }^{15}$ Não se realizaram buscas de legislação municipal, porque, além de existirem 5.570 municípios no Brasil, o que já inviabiliza a tarefa por si só, um grande número das municipalidades brasileiras não conta com sistema eletrônico de consulta legislativa.

${ }^{16}$ Ao que tudo indica, essa é a primeira lei brasileira compelindo empreendedores à contratação de seguro de responsabilidade civil por dano ambiental como condicionante do licenciamento ambiental.
} 
Parágrafo único - Esta Lei aplica-se a barragens e açudes destinados à acumulação de água para quaisquer usos, à disposição final ou temporária de rejeitos e à acumulação de resíduos industriais que apresentem pelo menos uma das seguintes características:

I - altura do maciço, contada do ponto mais baixo da fundação à crista, maior ou igual a 10m (dez metros), caso construída em concreto ou cimento e maior ou igual a $5 \mathrm{~m}$ (cinco metros), caso construída em solo;

II - capacidade total do reservatório maior ou igual a $2.000 .000 \mathrm{~m}^{3}$ (dois milhões de metros cúbicos), caso construída em concreto e maior ou igual a 1.000 .000 $\mathrm{m}^{3}$ (hum milhão de metros cúbicos), se construída em solo;

III - reservatório que contenha resíduos perigosos conforme normas técnicas aplicáveis;

IV - categoria de dano potencial associado, médio ou alto, em termos econômicos, sociais, ambientais ou de perda de vidas humanas, conforme definido na classificação do art. 3o desta Lei.

Uma emenda parlamentar apresentada ao projeto impôs ao empreendedor, assim entendido como o "agente privado ou governamental com direito real sobre as terras onde se localiza a barragem, o açude e o reservatório ou que explore a barragem ou o açude para benefício próprio ou da coletividade" (art. 2으, inciso V), a contratação de seguro de responsabilidade civil por dano ambiental, nos seguintes termos:

Art. 14 - Deverá o empreendedor contratar seguro contra desastres, cujo valor da cobertura deverá ser determinado pelo órgão ambiental estadual competente, levando-se em consideração a complexidade e os riscos do empreendimento, e os valores necessários para execução das ações emergenciais e a recuperação integral da população e meio ambiente afetado.

Esse dispositivo foi vetado pelo Governador do Estado, contudo o veto foi rejeitado pela Assembleia Legislativa.

Por último, chama atenção que a Lei no 7.192/2016 não estipulou a consequência jurídica para a hipótese de descumprimento de seu art. 14, o que suscita dúvidas quanto a sua correta aplicação (vide nota de rodapé $n$ 웅)

No estado do Rio Grande do Sul, o art. 39 da Lei no 14.258, de 16 de abril de 2014, que institui a Política Estadual de Resíduos Sólidos, primeiro resultado encontrado, é idêntico ao art. 40 da PNRS.

O outro resultado da busca foi a Lei no 15.434, de 09 de janeiro de 2020, que institui o Código Estadual do Meio Ambiente do Rio Grande do Sul: 
Art. 190. Para todo empreendimento mineiro, independentemente da fase em que se encontra, será exigido o Plano de Controle Ambiental, cujas diretrizes serão estabelecidas pelo órgão ambiental competente.

$\S 1$ O O órgão ambiental poderá exigir do interessado a contratação de seguro de responsabilidade civil de riscos ambientais, ou outra forma de garantia, conforme regulamentação.

$\S 2$ 20 Conselho Estadual do Meio Ambiente definirá quais os empreendimentos ou atividades consideradas de significativo impacto ambiental poderão ser objeto de contratação de seguro de responsabilidade civil de riscos ambientais, ou outra forma de garantia, conforme regulamentação.

Essa opção legislativa de vincular a faculdade do órgão ambiental de exigir a contratação de seguro de responsabilidade civil por dano ambiental, ou outra forma de garantia, a empreendimentos ou atividades considerados de significativo impacto ambiental será comentada adiante (vide tópico V).

No estado de São Paulo, achou-se a Lei no 12.300, de 16 de março de 2006, que apenas lista "o incentivo ao seguro ambiental" como um dos instrumentos da Política Estadual de Resíduos Sólidos (art. 4으, inciso XXII), à semelhança da PNMA.

E também foi encontrada a Lei no 13.577 , de 08 de julho de 2009, que dispõe sobre diretrizes e procedimentos para a proteção da qualidade do solo e gerenciamento de áreas contaminadas, que compele o responsável legal por área contaminada a apresentar garantia bancária ou seguro ambiental, "a fim de assegurar que o Plano de Remediação aprovado seja implantado em sua totalidade e nos prazos estabelecidos, no valor mínimo de $125 \%$ (cento e vinte e cinco por cento) do custo estimado do Plano de Remediação" (art. 25, § 2ํ).

Todavia, trata-se de seguro-garantia, e não de seguro de responsabilidade civil, razão pela qual está fora do escopo deste trabalho.

No estado do Tocantins, o art. 57 da Lei no 3.614, de 18 de dezembro de 2019, que institui a Política Estadual de Resíduos Sólidos, único resultado pertinente obtido, é uma transcrição quase literal do art. 40 da PNRS.

Nos estados do Acre, do Amapá, de Alagoas, da Bahia, do Ceará, de Goiás, do Maranhão, de Mato Grosso, de Mato Grosso do Sul, de Minas Gerais, da Paraíba, do Paraná, do Piauí, do Rio Grande do Norte, de Roraima, de Santa Catarina, de Sergipe e do Tocantins, bem como no Distrito Federal, o motor de busca dos sítios eletrônicos das respectivas Casas Legislativas ou não encontrou qualquer resultado ou os resultados apresentados não tinham relação alguma com seguro de responsabilidade civil por dano ambiental. 
E nos estados do Amazonas e de Roraima, não foi possível realizar a busca, porque não existe sistema de consulta legislativa nos sítios eletrônicos das respectivas Assembleias Legislativas.

\section{III - DOS PROJETOS DE LEI EM TRAMITAÇÃO NO CONGRESSO NACIONAL}

Além da legislação estadual de regência, esta investigação também realizou um levantamento dos projetos de lei sobre seguro de responsabilidade civil por dano ambiental em tramitação no Congresso Nacional. Para o levantamento das proposições, foram realizadas buscas por palavras-chave no dia 16 de julho de 2020, utilizando-se o termo "seguro ambiental" (sem aspas), nos sítios eletrônicos do Senado Federal e da Câmara dos Deputados.

No Senado Federal, a busca não encontrou proposições legislativas em tramitação. Nada obstante, o PLS no 767/2015, de autoria do ex-senador Valdir Raupp (MDB/RO), fora aprovado sem emendas e em caráter terminativo, nos termos do substitutivo apresentado pelo relator da Comissão de Meio Ambiente, em 12 de junho de 2018 e remetido à Câmara dos Deputados em 26 de junho de $2018 .^{17}$

Esse projeto acrescenta os $\S \S 5$ e 6으 ao art. 10 da Lei no 6.938/1981, para facultar ao órgão ambiental exigir seguro ambiental (leia-se seguro de responsabilidade civil por dano ambiental) quando for necessária a elaboração de estudo de impacto ambiental e de relatório de impacto ambiental (EIA/Rima), nos seguintes termos:

Art. 10. [...]

§ 5o Sem prejuízo dos demais requisitos aplicáveis ao licenciamento ambiental, o órgão ambiental licenciador deverá se manifestar, nos casos em que for necessária a elaboração de Estudo de Impacto Ambiental (EIA) e de Relatório de Impacto Ambiental (Rima), sobre a necessidade de comprovação da contratação do seguro ambiental previsto no inciso XIII do art. 9o desta Lei como condição para a concessão da licença ambiental para início da operação de empreendimentos ou atividades utilizadores de recursos ambientais, efetiva ou potencialmente poluidores ou capazes, sob qualquer forma, de causar degradação ambiental.

§ 60 O valor segurado do seguro ambiental será fixado na fase inicial do licenciamento pelo órgão ambiental licenciador, conforme critérios objetivos estabelecidos em regulamento. (NR)

17 Cf. Parecer do Rel. Sen. Flexa Ribeiro. Disponível em: https://legis.senado.leg.br/sdleggetter/documento?dm=7726641\&ts=1593937997091\&disposition=inline. Acesso em: 16 jul. 2020. 
Essa opção legislativa de permitir que o órgão ambiental se manifeste sobre a necessidade de comprovação da contratação de seguro de responsabilidade civil por dano ambiental para empreendimentos ou atividades sujeitos a EIA/Rima será comentada adiante (vide tópico V).

Na Câmara dos Deputados, a busca encontrou o PL no 3.729/2004, o PL no 10.494/2018 (numeração dada ao PLS no 767/2015) e, apensados a este, o PL no 2.313/2003, o PL no 3.876/2008, o PL no 10.412/2018 e o PL no 153/2019.

O PL no 3.729/2004, de autoria dos ex-deputados Luciano Zica (PT-SP), Walter Pinheiro (PT-BA) e Zezéu Ribeiro (PT-BA), dispõe sobre o licenciamento ambiental e regulamenta o inciso IV do § 1 으 do art. 225 da CR. Em sua versão original, o projeto previa a faculdade de o órgão licenciador exigir a contratação de seguro de responsabilidade civil por dano ambiental, nos seguintes termos:

Art. 10. Na concessão de licença ambiental, o licenciador deve exigir que o empreendedor adote medidas capazes de assegurar que as matérias-primas e outros insumos, os processos de produção e os bens produzidos tenham padrão de qualidade e procedimentos técnicos que eliminem ou reduzam os efeitos prejudiciais sobre o meio ambiente.

Parágrafo único. Além do disposto no caput, o licenciador pode exigir:

I- a realização periódica de auditorias ambientais;

II - a contratação de seguro de responsabilidade civil por dano ambiental.

Na versão atual do projeto, apresentada em 26 de novembro de 2018, fruto duma subemenda do relator, ex-deputado Marcos Rogério, na Comissão de Constituição e Justiça e de Cidadania (CCJC), não subsiste qualquer menção a seguro.

A última ação legislativa do projeto foi a designação de relator na CCJC, deputado João Roma (Republicanos-BA), em 04 de outubro de 2019.

O PL no 10.494/2018 ainda não teve tramitação relevante na Casa, sendo sua última ação legislativa a designação de relator na CCJC, deputado Felipe Francischini (PSL-PR), em 20 de dezembro de 2019.

O PL no 2.313/2003 teve origem na Sugestão no 43/2003 feita pela Ação Total dos Indivíduos da Terra Unidos em Defesa da Ecologia à Comissão de Legislação Participativa em 17 de junho de 2003. Esse projeto traz uma série de provisões, entre as quais a inclusão de uma alínea " $\mathrm{n}$ " no art. 20 do Decreto-Lei no 73, de 21 de novembro de 1966, que dispõe sobre o Sistema Nacional de Seguros Privados, para tornar obrigatório "o seguro de responsabilidade civil do poluidor, pessoa física ou 
jurídica que exerça atividade econômica potencialmente causadora de degradação ambiental", nos seguintes termos:

Art. $20 \mathrm{O}$ art. 20 do Decreto-Lei no 73, de 21 de novembro de 1966, que "dispõe sobre o Sistema Nacional de Seguros Privados e regula as operações de seguros e resseguros e dá outras providências", passa a vigorar acrescido da seguinte alínea " $n$ ":

"Art. 20. Sem prejuízo do disposto em leis especiais, são obrigatórios os seguros de:

[...] n) responsabilidade civil do poluidor, pessoa física ou jurídica que exerça atividades econômicas potencialmente causadoras de degradação ambiental, por danos a pessoas e ao meio ambiente em zonas urbanas ou rurais." (NR)

O PL no 2.313/2003, apesar de ter por "finalidade dar cobertura a pessoas e ecossistemas por danos relacionados à degradação ambiental em zonas urbanas ou rurais" (art. 3ำ), é um projeto de lei que se insere na dimensão legislativa civilista do contrato de seguro. Seu pano de fundo é ambiental ("responsabilidade civil do poluidor"), mas sua regulação é majoritariamente de direito de seguro: pessoa responsável pelo cálculo do valor do prêmio (art. 3ํ, parágrafo único); abrangência da garantia (arts. 4ㅇ a 6ㅇ); beneficiários da indenização (arts. 7ํㅜ a 9ㅇ); regras para as seguradoras (arts. 10 e 12); e previsão de regulamentação pelo Conselho Nacional de Seguros Privados (art. 15). As exceções ficam por conta dos arts. 2ํ, 13 (vinculação de ato público de liberação à contratação de seguro) e 14 (previsão de multa por não contratação de seguro), que carreiam normas de direito econômico dirigidas ao empreendedor - aliás, inconstitucionais por violação ao princípio da autonomia municipal (arts. 18, 24, § 1ํ, e 34, inciso VII, alínea “c").

Em 21 de setembro de 2005, a Comissão de Meio Ambiente e Desenvolvimento Sustentável (CMADS) votou favoravelmente ao projeto, nos termos do parecer do relator, apresentando sete emendas modificativas e uma emenda aditiva. ${ }^{18}$

Em 03 de outubro de 2007, a Comissão de Finanças e Tributação votou pela compatibilidade e adequação financeira e orçamentária das proposições, porém rejeitou, no mérito, tanto o projeto quanto as emendas da CMADS, por entender que "apresentam equívocos que em nada contribuiriam

18 Cf. Parecer do Rel. Dep. Leonardo Monteiro. Disponível em: https://www.camara.leg.br/proposicoesWeb/prop_mostrarintegra?codteor=340130\&filename=ParecerCMADS-15-09-2005 Acesso em: 16 jul. 2020. 
para minorar consequências de possíveis danos ambientais e que tampouco aprimorariam atividades do setor de seguros". ${ }^{19}$

Apensado ao PL no 2.313/2003 em 04 de setembro de 2008, o PL no 3.876/2008, de autoria do ex-deputado Rogerio Lisboa (DEM-RJ), altera a Lei no 6.938/1981, para prever a contratação opcional de seguro de responsabilidade civil por risco e dano ambiental, no momento da emissão da licença ambiental prévia, como forma de permitir o início imediato da obra, nos seguintes termos:

Art. 1․ 0 art. 10 da Lei no 6.938, de 31 de agosto de 1981, que "dispõe sobre a Política Nacional do Meio Ambiente, seus fins e mecanismos de formulação e aplicação, e dá outras providências", passa a vigorar acrescido do seguinte $\S 5$ : “Art. 10. [...]

$\S 5$ o Sem prejuízo de outras exigências estabelecidas no âmbito do processo de licenciamento ambiental, fica facultado ao empreendedor a contratação de Apólice de Seguro por Risco e Dano de Responsabilidade Civil Ambiental, imediatamente após a concessão da Licença Prévia.

I - a contratação, pelo empreendedor, de Seguro por Risco e Dano de Responsabilidade Civil Ambiental, no momento da emissão da Licença Prévia, que aprova a viabilidade ambiental do empreendimento, autoriza o mesmo a dar início às obras.

II - caberá ao órgão licenciador responsável, o estabelecimento do valor final da Apólice, a aceitabilidade dos termos e condições pactuados, bem como a aprovação da Seguradora ou Seguradoras contratadas."

O PL no 3.876/2008 faculta ao empreendedor, com a mera contratação de seguro de responsabilidade civil por dano ambiental, iniciar as obras já no momento da emissão da licença prévia. Esta é um instrumento preliminar de controle ambiental, que apenas aprova a localização e a concepção de um empreendimento ou atividade, atesta sua viabilidade ambiental, seus requisitos e condicionantes básicos. O detalhamento do projeto básico é feito na fase da licença de instalação, momento em que o empreendedor apresenta o projeto executivo do empreendimento ou atividade. A supressão dessa etapa no licenciamento ambiental inviabiliza a concordância prática dos interesses socioambientais com os interesses econômicos, uma vez que a obra é instalada antes mesmo de o órgão ambiental aferir se os requisitos e condicionantes básicos fixados na licença prévia foram cumpridos pelo empreendedor, frustrando o princípio do desenvolvimento sustentável - sobre o qual se discorrerá adiante.

19 Cf. Parecer do Rel. Dep. José Pimentel. Disponível em: https://www.camara.leg.br/proposicoesWeb/prop_mostrarintegra?codteor=501383\&filename=Parecer-CFT06-09-2007. Acesso em: 16 jul. 2020. 
Em 20 de agosto de 2013, a CCJC votou pela constitucionalidade, juridicidade e inadequada técnica legislativa do PL no 2.313/2003, pela constitucionalidade, juridicidade e adequada técnica legislativa do PL no 3.876/2008 e de todas as emendas apresentadas pela CMADS, e, no mérito, votou pela rejeição de todas as proposições. ${ }^{20}$

Em 13 de julho de 2018, contudo, a última ação legislativa referente ao PL no 2.313/2003 e ao PL no 3.876/2008 foi o recebimento deles apensados ao PL no 10.494/2018, pela CCJC.

O PL no 10.412/2018, de autoria do ex-deputado Deley (PTB-RJ), acrescenta um § 5 ao art. 10 da Lei no 6.938/1981, para facultar ao órgão licenciador, como requisito para a concessão ou renovação da licença ambiental, exigir do empreendedor a contratação de seguro de responsabilidade civil por dano ambiental, nos seguintes termos:

Art. 100 art. 10 da Lei no 6.938 , de 31 de agosto de 1981, que "dispõe sobre a Política Nacional do Meio Ambiente, seus fins e mecanismos de formulação e aplicação, e dá outras providências", passa a vigorar acrescido do seguinte $\S 5$ o: "Art. 10. [...]

$\S 5$ o Sem prejuízo de outras exigências estabelecidas no âmbito do processo de licenciamento ambiental, o órgão licenciador pode exigir do empreendedor, como requisitos para concessão ou renovação da licença ambiental:

I- a contratação de seguro de responsabilidade civil por dano ambiental;

II - a realização de audiências públicas sobre o impacto do empreendimento;

III - a realização periódica de auditoria ambiental de setores específicos ou de todo o empreendimento; e

IV - a manutenção de técnicos especializados em meio ambiente nos quadros funcionais da pessoa jurídica responsável pelo empreendimento licenciado, para acompanhar o funcionamento deste, ou a contratação de terceiros, em caráter permanente, com a mesma finalidade". (NR)

Esse projeto não recebeu qualquer parecer da Casa, e a última ação legislativa referente a ele foi seu recebimento pela CCJC em apenso ao PL no 3.876/2008, em 13 de julho de 2018.

O PL no 153/2019, de autoria do deputado José Nelto (Podemos-GO), é idêntico ao PL no 10.412/2018, inclusive a justificativa apresentada. Esse projeto não recebeu qualquer parecer da Casa, e a última ação legislativa referente a ele foi seu recebimento pela CCJC em 14 de julho de 2018, depois de apensado ao PL no 10.412/2008.

20 Cf. Parecer do Rel. Dep. Moreira Mendes. Disponível em: https://www.camara.leg.br/proposicoesWeb/prop_mostrarintegra?codteor=1117959\&filename=Parecer-CCJC20-08-2013. Acesso em: 16 jul. 2020. 
Ambos os projetos se inserem na dimensão legislativa ambientalista do contrato de seguro. Por um lado, ao investirem explicitamente os órgãos licenciadores de poder para exigir dos empreendedores a contratação de seguro de responsabilidade civil como condicionante do licenciamento ambiental, os projetos dissipam a celeuma hoje instaurada sobre o cabimento dessa exigência. Por outro lado, os projetos pecam pelo excesso de discricionariedade conferida ao órgão ambiental licenciador, já que não indicam os tipos de empreendimentos ou atividades dependentes de contratação de seguro e em quais circunstâncias essa contratação é obrigatória ou facultativa - o que poderia ser corrigido mediante a limitação de sua eficácia à edição de regulamento (vide tópico IV).

Em última análise, não é demais lembrar que, situando-se o direito ambiental no âmbito da legislação concorrente (art. 24, VI, VII e VIII), a competência da União limita-se ao estabelecimento de normas gerais (art. 24, § 1ํ). Isso significa que eventual lei federal que vier a condicionar - e não somente facultar - o licenciamento ambiental à contratação de seguro de responsabilidade civil por dano ambiental só será vinculante para os órgãos licenciadores federais.

\section{IV - DO ALCANCE DO PRINCÍPIO DA RESERVA DE LEI}

Mapeados a legislação estadual e os projetos de lei em tramitação no Congresso Nacional sobre seguro de responsabilidade civil por dano ambiental, é chegado o momento de avaliar até que ponto podem os órgãos licenciadores, à luz do princípio da reserva de lei, exigir a contratação de seguro de responsabilidade civil por danos ambientais, como condicionante do licenciamento ambiental de empreendimentos ou atividades, sem expressa previsão legal.

O princípio da reserva de lei é uma norma jurídica polissêmica, que se desdobra em quatro vertentes distintas: (I) a dicotomia reserva de lei formal e reserva de lei material; (II) a dicotomia reserva de lei absoluta e reserva de lei relativa; (III) a dicotomia reserva de lei qualificada e reserva de lei simples; e (IV) a reserva de lei de valor reforçado.

Reserva de lei formal significa que determinadas matérias só podem ser tratadas por leis emanadas do Poder Legislativo. ${ }^{21}$ Reserva de lei material significa que a determinadas matérias basta

\footnotetext{
${ }^{21}$ São leis em sentido formal, ou simplesmente leis formais, apenas as leis complementares e as leis ordinárias.
} 
o tratamento por normas jurídicas de natureza geral e abstrata e com fundamento imediato de validade na Constituição ou numa lei de valor reforçado. ${ }^{22}$

Reserva de lei absoluta significa que o tratamento de determinada matéria seja integralmente realizado por lei formal. Reserva de lei relativa significa que, apesar de necessária a edição de lei formal, ela não precisa esgotar o tratamento da matéria, cabendo complementá-la mediante normas infralegais, respeitados os limites ou requisitos fixados na lei formal. ${ }^{23-24}$

Reserva de lei qualificada significa que a restrição ao âmbito de proteção de determinado direito exige, além de previsão em lei, o atendimento às condições especiais, aos fins a serem perseguidos ou aos meios a serem utilizados, estabelecidos na Constituição. Reserva de lei simples significa que a restrição de determinado direito exige tão somente previsão em lei. ${ }^{25-26}$

Reserva de lei de valor reforçado significa que certas leis monopolizam o tratamento de determinadas matérias com afastamento de qualquer outra lei (exclusividade), são o pressuposto normativo necessário de outras leis (parametricidade) ou devem ser respeitadas por outras leis (primariedade). ${ }^{27-28}$

\footnotetext{
22 São leis em sentido material, ou simplesmente leis materiais, as leis delegadas, as medidas provisórias, os regulamentos autônomos, os regulamentos independentes e os mandados de injunção com eficácia erga omnes. ${ }^{23} \mathrm{Cf}$. MORAES, Alexandre de. Direito Constitucional, 22. ed. São Paulo: Atlas, 2007, p. 38.

${ }^{24} \mathrm{O}$ art. 220, § 4으, da CR ("A propaganda comercial de tabaco, bebidas alcoólicas, agrotóxicos, medicamentos e terapias estará sujeita a restrições legais, nos termos do inciso II do parágrafo anterior, e conterá, sempre que necessário, advertência sobre os malefícios decorrentes de seu uso.") é exemplo de reserva de lei absoluta. 0 art. 153, § 1ㅇ, da CR ("É facultado ao Poder Executivo, atendidas as condições e os limites estabelecidos em lei, alterar as alíquotas dos impostos enumerados nos incisos I, II, IV e V.") é exemplo de reserva de lei relativa.

${ }^{25}$ Cf. MENDES, Gilmar Ferreira; BRANCO, Paulo Gustavo Gonet. Curso de Direito Constitucional, 14. ed. São Paulo: Saraiva, 2019, p. 203-209.

${ }^{26} \mathrm{O}$ art. 5o, inciso XIII, da CR ("é livre o exercício de qualquer trabalho, ofício ou profissão, atendidas as qualificações profissionais que a lei estabelecer;") é exemplo de reserva de lei qualificada. $\mathrm{O}$ art. 50 , inciso XV, da CR ("é livre a locomoção no território nacional em tempo de paz, podendo qualquer pessoa, nos termos da lei, nele entrar, permanecer ou dele sair com seus bens;") é exemplo de reserva de lei simples.

27 Cf. CANOTILHO, José Joaquim Gomes. Direito constitucional e teoria da Constituição, 7. ed. Coimbra: Almedina, 2003, p. 697-698.

${ }^{28}$ A lei orgânica municipal é exemplo de lei de valor reforçado pela exclusividade, pois é a única legitimada para reger a autonomia política do município (art. 29 da CR); a lei complementar de normas gerais tributárias é exemplo de lei de valor reforçado pela parametricidade, pois é o pressuposto normativo necessário às leis que exigem ou aumentam tributo (art. 146, inciso III, c/c art. 150, inciso I, ambos da CR); e o plano diretor é exemplo de lei de valor reforçado pela primariedade, pois "os municípios com mais de vinte mil habitantes e o Distrito Federal podem legislar sobre programas e projetos específicos de ordenamento do espaço urbano por meio de leis que sejam compatíveis com as diretrizes fixadas no plano diretor" (RE 607.940/DF).
} 
Por um lado, a jurisprudência do Supremo Tribunal Federal já se firmou no sentido de que "nenhum ato regulamentar pode criar obrigações ou restringir direitos, sob pena de incidir em domínio constitucionalmente reservado ao âmbito de atuação material da lei em sentido formal". ${ }^{29}$

Regulamento é uma norma jurídica geral e abstrata editada pelo Poder Executivo, quer para desenvolver e executar fielmente as leis, quer para exercer autonomamente competências diretamente delimitadas pela Constituição, quer para atuar residualmente nos espaços deixados pelo legislador em matérias que não contrariem a reserva de lei e o próprio texto legal. ${ }^{30}$

Os regulamentos executivos são explicitamente previstos pela Constituição ${ }^{31}$ com a finalidade de "explicar o modo e a forma de execução da lei" ${ }^{32}$, pois "o cumprimento de determinadas leis pressupõe uma interferência de órgãos administrativos para a aplicação do que nelas se dispõe" ${ }^{33}$. Os regulamentos autônomos são explicitamente previstos pela Constituição ${ }^{34}$, com conteúdo bastante delimitado e reservado, constituindo "um campo exclusivo no qual o legislador não pode interferir". ${ }^{35}$ Os regulamentos independentes "existem no espaço deixado pelo legislador em matérias que não contrariem a reserva de lei e o próprio texto legal, num 'campo de poderes residuais'”, por essa razão "estão sujeitos à preeminência de lei, o que significa que, havendo lei posterior sobre o assunto, esta substitui tal regulamento". ${ }^{36}$

${ }^{29}$ AC 1.033 AgR-QO/DF (Tribunal Pleno). Diário de Justiça 16 jun. 2006. Rel. Min. Celso de Mello.

${ }^{30}$ Perfilha-se neste artigo a doutrina trialista de André Rodrigues Cyrino, para quem os regulamentos podem ser executivos, autônomos ou independentes, cf. O poder regulamentar autônomo do Presidente da República: a espécie regulamentar criada pela EC no 32/2001. Belo Horizonte: Fórum, 2005, p. 67; 94. Defendendo uma doutrina dualista, que divide os regulamentos em executivos e autônomos, estes sem distinção para os regulamentos independentes, cf. BINENBOJM, Gustavo. Uma teoria do direito administrativo: direitos fundamentais, democracia e constitucionalização, 3. ed. Rio de Janeiro: Renovar, 2014, p. 175-176. Defendendo uma doutrina monista, segundo a qual só existem regulamentos executivos no direito brasileiro, cf. CARVALHO FILHO, José dos Santos. Manual de direito administrativo. Rio de Janeiro: Lumen Juris, 2007, p. 52-54.

31 “Art. 84. Compete privativamente ao Presidente da República:

[...] IV - sancionar, promulgar e fazer publicar as leis, bem como expedir decretos e regulamentos para sua fiel execução;

“Art. 87. [...] Parágrafo único. Compete ao Ministro de Estado, além de outras atribuições estabelecidas nesta Constituição e na lei:

[...] II - expedir instruções para a execução das leis, decretos e regulamentos;"

32 MEIRELLES, Hely Lopes. Direito administrativo brasileiro, 16. ed. atual. Constituição de 1988. São Paulo: Revista dos Tribunais, 1991, p. 108.

${ }^{33}$ MELLO, Celso Antônio Bandeira de. Curso de Direito Administrativo, 33. ed. São Paulo, Malheiros, 2017, p. 363.

34 “Art. 84. Compete privativamente ao Presidente da República:

[...] VI - dispor, mediante decreto, sobre:

a) organização e funcionamento da administração federal, quando não implicar aumento de despesa nem criação ou extinção de órgãos públicos;"

${ }^{35}$ CYRINO, André Rodrigues. op. cit., p. 94.

${ }^{36}$ Idem, ibidem, p. 94-95. 
Por outro lado, o mesmo Supremo Tribunal Federal, ao apreciar recurso extraordinário contra a cobrança de outorga onerosa do direito de construir no município de Florianópolis - SC, assim distinguiu os conceitos de dever, obrigação e ônus, nos termos do voto do relator Min. Eros Grau:

O dever jurídico consubstancia precisamente uma vinculação ou limitação imposta à vontade de quem por ele alcançado. Definido como tal pelo ordenamento jurídico, o dever há de ser compulsoriamente cumprido, sob pena de sanção jurídica - o seu não atendimento configura comportamento ilícito. [...] A obrigação [...] supõe uma situação de dever, em que se coloca o devedor. Não obstante, é certo que o conceito de dever transcende o âmbito do Direito das Obrigações: há deveres jurídicos que não compreendem obrigação de nenhuma espécie.

[...] a obrigação consubstancia um vínculo em razão do qual uma pessoa [devedor] deve a outra [credor] o cumprimento de uma certa prestação. A obrigação consubstancia um direito relativo, na medida em que o crédito que dela decorre apenas pode ser exigido, pela pessoa ou pluralidade de pessoas dele titular, contra a pessoa ou pluralidade de pessoas na situação de devedor. [...] falamos de ônus quando o exercício de uma faculdade é definido como condição para a obtenção de uma certa vantagem; para tanto, o ônus é uma faculdade cujo exercício é necessário para a realização de um interesse. [...] dever e ônus têm em comum o elemento formal, consistente no vínculo à vontade, mas diverso o elemento substancial, porque o vínculo é imposto, quando se trata de dever, no interesse alheio, e, tratando-se de ônus, para a tutela de um interesse próprio.

[...] Por isso que o não cumprimento do ônus não acarreta, para o sujeito, sanção jurídica, mas tão-somente uma certa desvantagem econômica: a não obtenção da vantagem, a não satisfação do interesse ou a não realização do direito pretendido. Já o não-cumprimento do dever - ou da obrigação - acarreta sanção jurídica para o sujeito. [...] Descreve-se o ônus, assim, como o instrumento através do qual o ordenamento jurídico impõe ao sujeito um determinado comportamento, que deverá ser adotado se não pretender ele arcar com consequências que the serão prejudiciais. Ou como um comportamento que o sujeito deve adotar para alcançar uma determinada vantagem, que consiste na aquisição ou na conservação de um direito.

[...] ato devido é aquele que o direito objetivo impõe na tutela de interesse alheio; ato necessário, o que o direito objetivo exige de quem quer conseguir um certo fim, correspondente ao seu próprio interesse. No primeiro caso, o dever; no segundo, ônus.

[...] poderemos distinguir de um lado o dever - e a obrigação - como vínculo imposto à vontade do sujeito em razão da tutela de interesse alheio e cujo descumprimento compreende um ilícito, importando a aplicação de sanção jurídica; de outro o ônus como vínculo imposto à vontade do sujeito como condição para a satisfação do seu próprio interesse e cujo descumprimento não importa a aplicação de sanção jurídica, mas tão-somente efeitos econômicos negativos.

A lei que estabelece o ônus não impõe a adoção de uma conduta pelo sujeito a ele vinculado, isto é, não fixa dever de conduta. Por isso não é dever; não se confunde nem com o dever, nem com a obrigação. Ao sujeito por ele vinculado não se impõe a adoção da conduta definida pelo ônus; resta-lhe a opção de não 
cumpri-la, se para tanto desistir da obtenção ou conservação de um direito. Pretendendo obtê-lo ou conservá-lo, todavia, há de necessariamente adotar aquela conduta, cujo cumprimento é condição para tal obtenção ou conservação. (Grifos do original) ${ }^{37}$

Como se percebe, dever é um vínculo imposto à vontade do sujeito em prol de interesse alheio (ato devido), cujo descumprimento configura ato ilícito e acarreta sanção jurídica para ele; obrigação é um caso específico de dever em que uma pessoa (credor) tem direito a uma prestação de outra (devedor), portanto somente dizendo respeito aos titulares duma dada relação jurídica; e ônus é um vínculo imposto à vontade do sujeito em prol de interesse próprio (ato necessário), cujo descumprimento não acarreta sanção jurídica, mas apenas uma desvantagem econômica consistente na impossibilidade de aquisição ou conservação dum direito.

Nessa ordem de ideias, a exigência de contratação de seguro de responsabilidade civil por dano ambiental como condicionante do licenciamento de empreendimento ou atividade caracterizase como um ônus, porque impõe um vínculo à vontade do empreendedor em prol de seu próprio interesse. 0 empreendedor que não contrata o seguro não sofre sanção jurídica, pois não pratica ato ilícito; ele apenas deixa de exercer uma faculdade, um ato necessário, que é condição para a obtenção ou conservação duma vantagem, qual seja a respectiva licença ambiental. ${ }^{38}$

Dentro dessa lógica, não se sustenta o argumento de que o condicionamento da licença ambiental à contratação de seguro de responsabilidade civil esbarra em reserva de lei formal, pois o que a Constituição da República reservou à lei foi a imposição de deveres ou obrigações ("ninguém será obrigado a fazer ou deixar de fazer alguma coisa senão em virtude de lei"), e não de ônus. ${ }^{39}$

${ }^{37}$ SUPREMO Tribunal Federal. RE 387.047/SC (Tribunal Pleno). Diário de Justiça Eletrônico 06 mar. 2008. Rel. Min. Eros Grau.

${ }^{38}$ É o que sucede com o descumprimento da regra do art. 14 da Lei do Estado do Rio de Janeiro no 7.192/2016, cuja consequência jurídica não foi objetivamente estabelecida pelo legislador. Embora nenhuma menção seja feita ao licenciamento ambiental nesse diploma legal, estando todas as referências ao órgão estadual relacionadas com a tarefa de fiscalização, não se pode perder de vista que a competência para fiscalizar decorre da competência para licenciar (art. 70, inciso XIII c/c art. 8ㅇ, inciso XIII c/c art. 9o, inciso XIII, todos da Lei Complementar no 140, de 08 de dezembro de 2011). Consequentemente, o descumprimento do art. 14 repercute no licenciamento ambiental, devendo importar na impossibilidade de obtenção da licença ou na perda dessa mesma licença, conforme seja o caso.

${ }^{39}$ Exemplo disso é a Resolução Antaq no 2.190, de 28 de julho de 2011, que disciplina "a prestação de serviços de retirada de resíduos de embarcações em áreas sob a jurisdição (sic) de instalações portuárias brasileiras", cujo Anexo I de seu Anexo exige seguro ambiental "englobando o ressarcimento dos custos de atendimento às emergências e danos causados por vazamentos, derramamentos e contaminações" para o credenciamento de empresas coletoras de resíduos de embarcações. 
A própria definição de licença ambiental, plasmada na Resolução Conama № 237, de 19 de dezembro de 1997, que dispõe sobre a revisão e complementação dos procedimentos e critérios utilizados para o licenciamento ambiental, já evidencia que "o órgão ambiental competente estabelece as condições, restrições e medidas de controle ambiental que deverão ser obedecidas pelo empreendedor" (art. 1으, inciso II) ${ }^{40}$.

Ademais, se o órgão ambiental tem a prerrogativa de simplesmente indeferir o pedido de licença quando considera, com base no estudo ambiental apresentado pelo empreendedor, que a instalação ou a operação do projeto é ambientalmente inviável (art. 8o, inciso I, c/c art. 10, inciso VIII, ambos da Resolução Conama no 237/1997) ${ }^{41}$, por muito maior razão pode condicionar a expedição da licença à prática de um ato necessário.

Não se quer dizer com isso que, ao impor um ônus no licenciamento ambiental, o órgão licenciador tem diante de si uma prerrogativa irrestrita e indiscriminada de vincular a vontade do empreendedor. É inequívoco que, se assim agir, ele estará violando, entre outros, o princípio da livre iniciativa.

O que se argumenta é que a fixação de condicionantes no licenciamento ambiental de empreendimentos ou atividades - neste particular, a contratação de seguro de responsabilidade civil por dano ambiental - prescinde de intermediação legislativa, colhendo sua legitimidade diretamente da Constituição da República (vide tópico V).

No entanto, para se garantir a segurança jurídica e a isonomia de tratamento dos empreendedores, bem assim para se coibirem desvios de poder e casuísmos no licenciamento ambiental, é indispensável que essa exigibilidade esteja devidamente regulamentada.

40 “Art. 10 Para efeito desta Resolução são adotadas as seguintes definições:

[...] II - Licença Ambiental: ato administrativo pelo qual o órgão ambiental competente, estabelece as condições, restrições e medidas de controle ambiental que deverão ser obedecidas pelo empreendedor, pessoa física ou jurídica, para localizar, instalar, ampliar e operar empreendimentos ou atividades utilizadoras dos recursos ambientais consideradas efetiva ou potencialmente poluidoras ou aquelas que, sob qualquer forma, possam causar degradação ambiental."

41 “Art. 8o O Poder Público, no exercício de sua competência de controle, expedirá as seguintes licenças:

I - Licença Prévia (LP) - concedida na fase preliminar do planejamento do empreendimento ou atividade aprovando sua localização e concepção, atestando a viabilidade ambiental e estabelecendo os requisitos básicos e condicionantes a serem atendidos nas próximas fases de sua implementação;

“Art. 10. O procedimento de licenciamento ambiental obedecerá às seguintes etapas:

[...] VIII - Deferimento ou indeferimento do pedido de licença, dando-se a devida publicidade." 
Logo, por não esbarrar em reserva de lei formal, o condicionamento do licenciamento ambiental à contratação de seguro de responsabilidade civil pode fundar-se em regulamento independente. Poder-se-ia falar aqui numa reserva de lei material. ${ }^{42}$

Superado o problema sobre se e como é exigível, sem previsão legal expressa, a contratação de seguro de responsabilidade civil por dano ambiental como condicionante do licenciamento ambiental, é chegado o momento de delimitar quando essa contratação é exigível.

\section{V - A DELIMITAÇÃO DOS TIPOS DE EMPREENDIMENTOS OU ATIVIDADES DEPENDENTES DE CONTRATAÇÃO DE SEGURO}

A legitimidade da delimitação dos tipos de empreendimentos ou atividades cujo licenciamento ambiental dependerá da contratação de seguro de responsabilidade civil por dano ambiental está diretamente relacionada com os fins perseguidos pela Administração Pública no uso de seu poder regulamentar.

Pois bem. A ordem econômica constitucional, fundada na valorização do trabalho humano e na livre iniciativa (art. 170), tem a "defesa do meio ambiente, inclusive mediante tratamento diferenciado conforme o impacto ambiental dos produtos e serviços de seus processos de elaboração e prestação", como um de seus princípios (art. 170, inciso VI). E em harmonia com a Constituição, constitui objetivo da PNMA a "compatibilização do desenvolvimento econômico social com a preservação da qualidade do meio ambiente e do equilíbrio ecológico" (art. 4ํㅡ, inciso I, da Lei no $6.938 / 1981)$.

Essa conciliação entre o desenvolvimento econômico-social e a preservação da qualidade do meio ambiente e do equilíbrio ecológico promove o chamado desenvolvimento sustentável, que "consiste na exploração equilibrada dos recursos naturais, nos limites da satisfação das necessidades e do bem-estar da presente geração, assim como de sua conservação no interesse das gerações futuras". ${ }^{43}$

\footnotetext{
42 “Em certas hipóteses, a 'reserva de lei' significa apenas exigência de uma disciplina normativa geral que pode ser alcançada através de actos normativos inferiores à lei. Neste sentido se alude a reserva de lei ou reserva de norma jurídica: necessária é uma norma mas não uma norma em forma de lei", CANOTILHO, José Joaquim Gomes. Direito constitucional e teoria da Constituição, 7. ed. Coimbra: Almedina, 2003, p. 728.

${ }^{43}$ SILVA, José Afonso da. Direito ambiental constitucional, 9. ed. São Paulo: Malheiros, 2011, p. 26-27.
} 
O princípio do desenvolvimento sustentável é o resultado da combinação duma série de princípios, quais sejam: (I) o princípio da integração, segundo o qual as políticas econômicas, sociais e ambientais devem ser integradas; (II) o princípio da equidade intergeracional, segundo o qual a preservação dos recursos naturais deve levar em conta as necessidades das presentes e futuras gerações; (III) o princípio da equidade intrageracional, segundo o qual a utilização dos recursos naturais deve priorizar as necessidades da população pobre mundial; e (IV) o princípio da preservação ambiental, segundo o qual os recursos naturais devem ser explorados de forma parcimoniosa. ${ }^{44}$

Como se nota, a ideia de desenvolvimento vai muito além de um mero processo quantitativo de aumento da produção econômica, de acumulação de capitais. ${ }^{45}$ Ele deve ser entendido também em sua dimensão qualitativa, no sentido de que, juntamente com o crescimento econômico, há de existir um correspondente benefício socioambiental. ${ }^{46}$

Seguindo essa lógica, parece correto afirmar que a função social extrínseca do contrato de seguro de responsabilidade civil por dano ambiental visa à defesa e à preservação do direito fundamental de todos, presentes e futuras gerações, "ao meio ambiente ecologicamente equilibrado, bem de uso comum do povo e essencial à sadia qualidade de vida" (art. 225 da CR).

Corolário desse direito fundamental, o princípio da reparação integral (art. 225, § 3ㅇ, da CR) ${ }^{47}$ encontra, no contrato de seguro de responsabilidade civil por dano ambiental, um instrumento de garantia de sua eficácia em caso de poluição causada por empreendedores insolventes. ${ }^{48}$

${ }^{44}$ Em sentido similar, cf. MACHADO, Paulo Affonso Leme. Direito ambiental brasileiro, 23. ed. São Paulo: Malheiros, 2015, p. 64.

${ }^{45}$ Cf. TZIRULNIK, Ernesto. op. cit., p. 69-70.

46 “Em síntese, o ecossistema terrestre é caracterizado pelas dimensões ecológica, econômica e social sabendo-se que a dimensão ecológica é a fundamental e indisponível para que a vida planetária se preserve e se perpetue. E quando se fala de dimensões, estas não são necessariamente medidas aritméticas, matemáticas ou geométricas: são simbólicas, porém reais, sem serem quantitativas. Não são lineares, nem quadradas, nem cúbicas: são abrangentes e totais, também qualitativas", MILARÉ, Édis. Direito do ambiente, 11. ed. São Paulo: Revista dos Tribunais, 2018, p. 1.023.

47 “Art. 225. [...] § 3으 As condutas e atividades consideradas lesivas ao meio ambiente sujeitarão os infratores, pessoas físicas ou jurídicas, a sanções penais e administrativas, independentemente da obrigação de reparar os danos causados."

${ }^{48}$ A jurisprudência do Superior Tribunal de Justiça é pacífica ao reconhecer que o sistema jurídico de proteção ambiental, disciplinado em normas constitucionais (art. 225, § 3으, da CR) e infraconstitucionais (arts. 2으 e 4음 da Lei no 6.938/1981), está fundado, entre outros, nos princípios da prevenção, do poluidor-pagador e da reparação integral. Com base nesse entendimento, admite a cumulação de obrigações de fazer, de não fazer e de pagar quantia para garantir a tutela integral do meio ambiente, cf., por todos, SUPERIOR Tribunal de Justiça. REsp 625.249/PR (Primeira Turma). Diário de Justiça 31 ago. 2006. Rel Min. Luiz Fux; e SUPERIOR Tribunal de Justiça. REsp 1.248.214/MG (Segunda Turma). Diário de Justiça Eletrônico 13 abr. 2012. Rel Min. Herman Benjamin. 
Outra repercussão da função social extrínseca do contrato de seguro de responsabilidade civil por dano ambiental, mesmo no caso de empreendedores solventes, é a estabilidade financeira proporcionada pela garantia de seu interesse legítimo na hipótese de danos ambientais de grande magnitude, o que possibilita a permanência de postos de trabalho e a continuidade normal das atividades. ${ }^{49}$

Uma última manifestação da função social extrínseca do contrato de seguro de responsabilidade civil por dano ambiental é que ele "transforma as seguradoras em verdadeiras parceiras do Poder Público", uma vez que "nenhuma seguradora concede cobertura a danos ambientais sem antes se certificar que o segurado tenha efetivamente adotado as medidas preventivas para se evitar a realização do sinistro [...], objetivando a minorar o risco do sinistro"..$^{50}$

Diante disso, a delimitação dos tipos de empreendimentos ou atividades cujo licenciamento ambiental dependerá da contratação de seguro de responsabilidade civil só terá legitimidade quando o ônus imposto aos empreendedores estiver justificado pela função social extrínseca do contrato.

Nesse sentido, o seguro de responsabilidade civil deve funcionar como uma caução do desenvolvimento sustentável e da reparação integral do dano ambiental, não devendo ser exigido senão para aqueles empreendimentos ou atividades que ponham em risco o equilíbrio ecológico do ambiente.

Sendo risco a "combinação da probabilidade de um evento e de suas consequências" (item 3.1.1 da ABNT ISO/IEC Guia 73:2005)51, a imposição do seguro de responsabilidade civil por dano ambiental se justifica, em maior ou menor medida, em função da relação existente entre o grau de possibilidade ou a frequência de um empreendimento ou atividade acarretar resultado adverso para o equilíbrio ecológico do ambiente e a magnitude desse mesmo resultado adverso.

Nesta altura, é essencial diferenciar conceitualmente impacto ambiental de dano ambiental, uma vez que ambos trazem consequências para o equilíbrio ecológico do ambiente.

A Resolução Conama № 1, de 23 de janeiro de 1986, que dispõe sobre critérios básicos e diretrizes gerais para a avaliação de impacto ambiental, traz a seguinte definição de impacto ambiental:

${ }^{49}$ Cf. MILARÉ, Édis. op. cit., p. 469.

${ }^{50}$ SHIH, Frank Larrúbia. Direito ambiental: a legislação em defesa dos recursos naturais. Revista de Informação Legislativa, ano 42, n. 165. Brasília: Senado Federal, jan./mar., 2005, p. 186-188.

${ }^{51}$ ASSOCIAÇÃO Brasileira de Normas Técnicas. ABNT ISO/IEC Guia 73:2005. Gestão de riscos - Vocabulário Recomendações para uso em normas. Rio de Janeiro: ABNT, 2005, p. 2. 
Art. 1ㅇ Para efeito desta Resolução, considera-se impacto ambiental qualquer alteração das propriedades físicas, químicas e biológicas do meio ambiente, causada por qualquer forma de matéria ou energia resultante das atividades humanas que, direta ou indiretamente, afetam:

I - a saúde, a segurança e o bem-estar da população;

II - as atividades sociais e econômicas;

III - a biota;

IV - as condições estéticas e sanitárias do meio ambiente;

$V$ - a qualidade dos recursos ambientais.

Da leitura da transcrição acima, verifica-se que impacto ambiental é o resultado de qualquer alteração física, química ou biológica do ambiente que afete aqueles elementos indicados nos incisos do dispositivo transcrito.

Ainda que comumente se associe a ideia de impacto com a de dano, tal associação não é necessariamente verdadeira, pois tanto existem alterações que afetam positivamente o ambiente quanto alterações que o afetam negativamente. Note-se que a própria Resolução Conama № 1/1986, ao determinar as atividades técnicas mínimas desenvolvidas no EIA, expressamente menciona os impactos positivos (benéficos) dos projetos:

Art. 60 0 estudo de impacto ambiental desenvolverá, no mínimo, as seguintes atividades técnicas:

[...] II - Análise dos impactos ambientais do projeto e de suas alternativas, através de identificação, previsão da magnitude e interpretação da importância dos prováveis impactos relevantes, discriminando: os impactos positivos e negativos (benéficos e adversos), diretos e indiretos, imediatos e a médio e longo prazos, temporários e permanentes; seu grau de reversibilidade; suas propriedades cumulativas e sinérgicas; a distribuição dos ônus e benefícios sociais.

[...] IV - Elaboração do programa de acompanhamento e monitoramento dos impactos positivos e negativos, indicando os fatores e parâmetros a serem considerados.

Também o art. 37 do Estatuto da Cidade (Lei № 10.257, de 10 de julho de 2001), que estabelece as diretrizes gerais da política urbana, quando trata do estudo de impacto de vizinhança, determina que ele contemple "os efeitos positivos e negativos" do empreendimento ou atividade. ${ }^{52}$

52 “Art. 37. O EIV será executado de forma a contemplar os efeitos positivos e negativos do empreendimento ou atividade quanto à qualidade de vida da população residente na área e suas proximidades, incluindo a análise, no mínimo, das seguintes questões:

I- adensamento populacional;

II - equipamentos urbanos e comunitários;

III - uso e ocupação do solo;

IV - valorização imobiliária; 
Além disso, mesmo a associação entre impacto ambiental negativo e dano ambiental é equivocada, porque:

\begin{abstract}
O impacto negativo ao meio ambiente é algo previsto e avaliado, logo, aceito, enquanto o dano não foi previsto e, consequentemente, gerenciado, não sendo aceito.

Impacto ambiental sempre ocorrerá, seja ele positivo, seja adverso ou negativo. 0 que o Direito Ambiental quer evitar pela via instrumento de licenciamento ambiental é o dano ambiental, a alteração do meio ambiente não prevista no processo decisório, pois se o impacto ambiental não foi previsto no licenciamento ambiental, o órgão licenciador não pôde realizar a ponderação adequada entre os valores concorrentes e nem gerenciar os impactos mediante mitigantes..$^{53}$
\end{abstract}

O impacto ambiental negativo é objeto de gestão de riscos, no procedimento de licenciamento ambiental, portanto as alterações adversas dele resultantes são sujeitas a análise prévia de risco, que determina as consequências de um empreendimento ou atividade e a probabilidade de sua ocorrência. O dano ambiental, ao contrário, é uma alteração adversa das características do ambiente imprevista, não gerenciada e, portanto, injusta - mas não necessariamente ilícita.

Por conseguinte, o interesse legítimo garantido mediante seguro de responsabilidade civil há de ser a indenização dos danos causados ao ambiente pelo empreendimento ou atividade do segurado, e não a indenização do impacto ambiental.

Exatamente porque os impactos ambientais são ponderados com vistas ao desenvolvimento sustentável, inclusive com a opção de não realização do empreendimento ou atividade, a potencial degradação ambiental avaliada nos estudos ambientais é internalizada pelo empreendedor como custo do licenciamento. Aquilo que não puder ser evitado ou, ao menos, mitigado, deverá ser compensado proporcionalmente a seu grau de impacto. ${ }^{54}$

V - geração de tráfego e demanda por transporte público;

$\mathrm{VI}$ - ventilação e iluminação;

VII - paisagem urbana e patrimônio natural e cultural.

Parágrafo único. Dar-se-á publicidade aos documentos integrantes do EIV, que ficarão disponíveis para consulta, no órgão competente do Poder Público municipal, por qualquer interessado."

${ }^{53}$ BIM, Eduardo Fortunato. Licenciamento ambiental, 4. ed. Belo Horizonte: Fórum, 2019, p. 75.

54 "Na gestão ambiental, compensar equivale a reparar um estrago infligido ao meio com a supressão ou o impacto negativo a um recurso natural ou bem ambiental. Essas perdas devem ser 'pesadas', ou seja, ponderadas, no sentido de que os ecossistemas ou o meio ambiente, no seu conjunto, não sofram diminuição quantitativa ou qualitativa dos seus componentes e atributos sem que algo se lhes dê em retribuição" (grifos do original), MILARÉ, Édis. op. cit., p. 1.101. 
Sem embargo, por um imperativo de ordem prática, a metodologia de cálculo do grau de impacto ambiental somente leva em consideração a degradação ambiental prevista para a implantação do empreendimento ou atividade, do contrário a cadeia compensatória regrediria ao infinito, inviabilizando o exercício de grande parte da atividade econômica no país.

Isso explica por que a Resolução Conama no 371, de 05 de abril de 2006, que estabelece diretrizes aos órgãos ambientais para o cálculo, cobrança, aplicação, aprovação e controle de gastos de recursos advindos de compensação ambiental, exclui do grau de impacto ambiental os "riscos da operação do empreendimento" (art. 2으, § 1ㅇ). ${ }^{55}$

Está bem de ver que não existe uma perfeita e necessária correspondência entre o grau de impacto de um empreendimento ou atividade e seu risco de degradação da qualidade do ambiente; tal correspondência é apenas circunstancial. Um empreendimento ou atividade de significativo impacto pode apresentar baixo risco, ao passo que um empreendimento ou atividade de alto risco pode apresentar baixo impacto.

Citem-se, a título ilustrativo, as operações de transferência de carga de óleo entre navios em águas jurisdicionais brasileiras (operações ship-to-ship), regulamentadas pela Instrução Normativa do Ibama $\mathrm{n}$ - 16, de 26 de agosto de 2013. Essa atividade causa baixo impacto, tanto que prescinde de licença, bastando mera autorização ambiental; contudo pode ser de alto risco, pelo cruzamento da tabela de frequência de ocorrência de danos (variando de extremamente remota a frequente) com a tabela de severidade de danos identificados (variando de desprezível a catastrófica), a ser apurado em estudo de análise de riscos apresentado pelo empreendedor (art. 13).

Por esse motivo, são criticáveis os $\S \S 1$ e 2ํ do art. 190 do Código Estadual do Meio Ambiente do Rio Grande do Sul e o PL no 10.494/2018 que facultam ao órgão ambiental licenciador exigir o seguro de responsabilidade civil apenas para empreendimentos ou atividades de significativo impacto ambiental.

55 “Art. 2ㅇ O órgão ambiental licenciador estabelecerá o grau de impacto ambiental causado pela implantação de cada empreendimento, fundamentado em base técnica específica que possa avaliar os impactos negativos e não mitigáveis aos recursos ambientais identificados no processo de licenciamento, de acordo com o EIA/RIMA, e respeitado o princípio da publicidade.

$\S 1$ ㅇ Para estabelecimento do grau de impacto ambiental serão considerados somente os impactos ambientais causados aos recursos ambientais, nos termos do art. 2으, inciso IV da Lei no 9.985, de 2000, excluindo riscos da operação do empreendimento, não podendo haver redundância de critérios.

$\S 2$ ㅇ Para o cálculo do percentual, o órgão ambiental licenciador deverá elaborar instrumento específico com base técnica, observado o disposto no caput deste artigo." 
Sendo assim, o que deve nortear o regulamento independente no qual se baseará a decisão do órgão ambiental licenciador para exigir o seguro de responsabilidade civil por dano ambiental é o grau de risco do empreendimento ou atividade, e não o potencial impacto.

O art. 19, inciso III, da Resolução Conama no $237 / 1997^{56}$ parece corroborar essa inteligência quando permite ao órgão ambiental competente "modificar os condicionantes e as medidas de controle e adequação, suspender ou cancelar uma licença expedida" diante da "superveniência de graves riscos ambientais e de saúde", desde que motive a decisão.

Dessa maneira, parece válido exigir a contratação de seguro de responsabilidade civil por dano ambiental em caso de empreendimentos ou atividades de alto risco, o que deve ser aferido em estudo de análise de risco apresentado pelo empreendedor. Por fim, como faz o art. 2ㅇ da Resolução Conama no 1/1986, que lista as atividades sujeitas a apresentação de EIA/Rima, o regulamento haveria de arrolar exemplificativamente os empreendimentos ou atividades sujeitos à realização de estudo de análise de risco.

\section{CONCLUSÃO}

Diante do exposto, parece confirmada a hipótese de que o órgão licenciador competente pode exigir a contratação de seguro de responsabilidade civil como condicionante do licenciamento ambiental, independentemente de intermediação legislativa, desde que prevista em regulamento independente e que o empreendimento ou a atividade apresente risco de dano grave, ou de difícil ou impossível reparação.

Em primeiro lugar, não se trata de imposição de dever ou obrigação, alcançado pelo princípio da reserva de lei (art. 5o, inciso II, da CR), mas de ônus. O descumprimento desse ônus não acarreta sanção jurídica para o empreendedor, e sim a impossibilidade de aquisição ou conservação duma licença ambiental.

Em segundo lugar, para se garantir a segurança jurídica e a isonomia de tratamento dos empreendedores, bem assim para se coibirem desvios de poder e casuísmos no licenciamento

56 “Art. 19. O órgão ambiental competente, mediante decisão motivada, poderá modificar os condicionantes e as medidas de controle e adequação, suspender ou cancelar uma licença expedida, quando ocorrer:

[...] III - superveniência de graves riscos ambientais e de saúde." 
ambiental, a condicionante concretamente estabelecida pelo órgão licenciador competente deve estar prevista em regulamento.

Em terceiro lugar, a delimitação dos tipos de empreendimentos ou atividades cujo licenciamento ambiental dependerá da contratação de seguro de responsabilidade civil só terá legitimidade quando o ônus imposto aos empreendedores estiver justificado pela função social extrínseca do contrato.

Em quarto lugar, o seguro de responsabilidade civil deve funcionar como uma caução do desenvolvimento sustentável e da reparação integral do dano ambiental, não podendo ser exigido senão para aqueles empreendimentos ou atividades que ponham em risco o equilíbrio ecológico do ambiente.

E em quinto lugar, o art. 19, inciso III, da Resolução Conama no 237/1997 parece validar a exigência de contratação de seguro de responsabilidade civil por dano ambiental em caso de empreendimentos ou atividades de alto risco, o que deve ser aferido em estudo de análise de risco apresentado pelo empreendedor.

\section{REFERÊNCIAS BIBLIOGRÁFICAS}

ASSOCIAÇÃO Brasileira de Normas Técnicas. ABNT ISO/IEC Guia 73:2005. Gestão de riscos Vocabulário - Recomendações para uso em normas. Rio de Janeiro: ABNT, 2005.

BIM, Eduardo Fortunato. Licenciamento ambiental, 4. ed. Belo Horizonte: Fórum, 2019.

BINENBOJM, Gustavo. Uma teoria do direito administrativo: direitos fundamentais, democracia e constitucionalização, 3. ed. Rio de Janeiro: Renovar, 2014.

CANOTILHO, José Joaquim Gomes. Direito constitucional e teoria da Constituição, 7. ed. Coimbra: Almedina, 2003. 
CARVALHO FILHO, José dos Santos. Manual de direito administrativo. Rio de Janeiro: Lumen Juris, 2007.

CAVALIERI FILHO, Sergio. Programa de responsabilidade civil, 9. ed. São Paulo: Atlas, 2010.

COELHO, Fábio Ulhoa. Curso de direito civil, 5. ed. São Paulo: Saraiva, v. 3 (Contratos), 2012.

CYRINO, André Rodrigues. O poder regulamentar autônomo do Presidente da República: a espécie regulamentar criada pela EC no 32/2001. Belo Horizonte: Fórum, 2005.

FARIAS, Cristiano Chaves de; ROSENVALD, Nelson. Curso de direito civil, 9. ed. Salvador: JusPodivm, v. 4 (Contratos), 2019.

GAGLIANO, Pablo Stolze; PAMPLONA FILHO, Rodolfo. Novo curso de direito civil, 2. ed. unificada. São Paulo: Saraiva, v. 4 (Contratos), 2019.

GONÇALVES, Carlos Roberto. Direito civil brasileiro, 14. ed. São Paulo: Saraiva, v. 3 (Contratos e atos unilaterais), 2017.

MACHADO, Paulo Affonso Leme. Direito ambiental brasileiro, 23. ed. São Paulo: Malheiros, 2015.

MEIRELLES, Hely Lopes. Direito administrativo brasileiro, 16. ed. atual. Constituição de 1988. São Paulo: Revista dos Tribunais, 1991.

MELLO, Celso Antônio Bandeira de. Curso de Direito Administrativo, 33. ed. São Paulo, Malheiros, 2017.

MENDES, Gilmar Ferreira; BRANCO, Paulo Gustavo Gonet. Curso de Direito Constitucional, 14. ed. São Paulo: Saraiva, 2019.

MILARÉ, Édis. Direito do ambiente, 11. ed. São Paulo: Revista dos Tribunais, 2018.

MORAES, Alexandre de. Direito Constitucional, 22. ed. São Paulo: Atlas, 2007. 
PEREIRA, Luciana Vianna. Seguro ambiental: o que a legislação pretende e do que o meio ambiente precisa? Revista de Eletrônica da OAB/RJ - Edição Especial - Direito Ambiental, 2017, p. 149-171. Disponível em: http://revistaeletronica.oabrj.org.br/wp-content/uploads/2017/11/PEREIRA-LucianaSeguro-Ambiental-1.pdf. Acesso em: 07 jul. 2020.

SHIH, Frank Larrúbia. Direito ambiental: a legislação em defesa dos recursos naturais. Revista de Informação Legislativa, ano 42, n. 165. Brasília: Senado Federal, jan./mar., 2005, p. 177-196.

SILVA, José Afonso da. Direito ambiental constitucional, 9. ed. São Paulo: Malheiros, 2011. Curso de direito constitucional positivo, 38. ed. São Paulo: Malheiros, 2015.

TZIRULNIK, Ernesto. Seguro de riscos de engenharia. Tese (Doutorado em Direito). Faculdade de Direito, Universidade de São Paulo. São Paulo, 2014.

Trabalho enviado em 04 de agosto de 2020 Aceito em 11 de fevereiro de 2021 